https://doi.org/10.48009/1_iis_2005_412-418

\title{
UNIVERSITY INTERNET POLICIES UNDER THE DIGITAL MILLENNIUM COPYRIGHT ACT: SWIFT JUDGMENT OR DUE PROCESS DENIED?
}

\author{
Bryan McKinney, Ouachita Baptist University, mckinneyb@obu.edu \\ David E. Griffith, Ouachita Baptist University, griffithd@obu.edu
}

\begin{abstract}
In an attempt to comply with requirements of the Digital Millennium Copyright Act, some universities have created policies that automatically suspend access to the university's Internet Service Provider (ISP) to students suspected of illegal file-sharing activity. In this paper, we argue that these policies may deprive students of their Constitutional right to due process.
\end{abstract}

Keywords: Digital Millennium Copyright Act, due process, file-sharing

\section{INTRODUCTION}

From the early efforts to develop a fair use doctrine, the historic relationship between copyright holders and the educational community is not without tension. Society is currently witnessing a struggle between these two groups involving the protection of intellectual property, and the use of technology. In a society that is becoming increasingly linked with technology, it is not surprising that most universities provide Internet access to students. The Internet may be used for many appropriate and productive purposes, such as on-line study, research, communication, and entertainment. However, students sometimes use the Internet to share files of copyrighted works of music and film.

To counter growing threats to intellectual property posed by new computer technologies such as file sharing, copyright law was amended in 1998 with the enactment of the Digital Millennium Copyright Act (DMCA) [1]. As documented in Sony v. Universal Studios [13] and Fonovisa v. Cherry Auction [3], only three types of copyright liability are historically recognized: direct infringement, contributory infringement, and vicarious infringement. The DMCA creates civil liability for Internet Service Providers (ISPs) even in the absence of direct, contributory, or vicarious infringement, as these terms have historically been understood. The DMCA imposes civil liability on an ISP that fails to act to prevent continuing access to copyrighted materials by its users [1]. A contribution of this paper is that we identify this new form of civil liability, which we call custodial infringement. Some universities have responded to the DMCA by developing policies that automatically deny access temporarily or permanently to students suspected of infringing copyrighted materials. Our research indicates that these policies may violate student's constitutional rights.

As agents of the government, state universities are required to enact policies that are consistent with the United States Constitution. Of particular interest to this writing is the Due Process Clause of the 14th Amendment, which requires state universities to establish appropriate procedures prior to the deprivation of a liberty interest, such as Internet access. Notice and an opportunity to be heard are commonly understood requirements of the $14^{\text {th }}$ Amendment. 
Automatic policies removing Internet access could violate the student's constitutional right to due process [5].

The relationship between students and private universities is beyond the scope of this paper, but it is worth a brief comment. This relationship is generally created by contractual rather than Constitutional principles. The Constitution limits government action, not private action. Thus, private universities have greater flexibility than state universities in dealing with allegations of Internet abuse. Nonetheless, many private university policies voluntarily incorporate due process standards (such as notice and a hearing) into student handbooks. In many cases, private university policies that result in automatic denial of Internet access without an appropriate appeals process may conflict with an implied or express contract between the university and student. In such cases, many of the opinions expressed in this article remain relevant.

\section{Review of DMCA \& Duties it Places on Universities}

The Digital Millennium Copyright Act (DMCA) was enacted in 1998 in an attempt to update copyright law against new threats resulting from electronic, and particularly digital, copies of intellectual properties [1]. Because computer technology is cheap and digital copies are nearly identical in quality to the original copyrighted work, officials representing the entertainment industry persuaded Congress that the danger to copyrighted electronic material was acute and that new legal protection was needed. The DMCA was primarily intended to prevent the sale and use of technology which overrode technical protection devices developed by industry, such as encryption and passwords.

As part of the broad attack on digital copyright infringement, the DMCA also targeted the procedures known as file-sharing. In file-sharing, users store digital copies of music on their personal computers, and various Internet-based software programs allow users to make available copies of their personal copy of the copyrighted material through the Internet.

The DMCA attempted to prohibit file-sharing with a two-pronged attack. Title I of the DMCA provided both criminal and civil penalties to users who allowed others or themselves to make copies of copyrighted material [1]. Title II provided civil penalties to Internet Service Providers who knowingly allowed the use of their Internet connection to make illegal copies [1].

The DMCA did create an avenue through which an educational institution could avoid liability. The first step is the appointment of a designated agent, who is charged with the responsibility of receiving notice from copyright holders of alleged violations of copyright law that take place by virtue of the University providing Internet access to its students. To avoid liability under the DMCA, Internet Service Providers must expeditiously remove or block access to allegedly infringing material [1].

In spite of the exemption afforded by the designated agent, the reality is that the DMCA created new duties for universities. In essence the DMCA made the university custodian for all copyrighted materials saved on, transferred across, or accessed through the university's Internet space. Universities that provided Internet access for students suddenly had increased legal exposure for students' potential misuse of the Internet for copyright infringement. 


\section{Attempts to Enforce the Law}

An issue central to this robust debate between copyright holders and the educational community is the subpoena power granted by the DMCA to copyright holders. The DMCA contains provisions allowing owners of copyright and their agents to subpoena Internet Service Providers for the identities of Internet users whom the copyright owner believes to be violating copyright laws. In particular, the Recording Industry Association of America (RIAA) has asked the courts to issue a series of subpoenas against universities and other Internet Service Providers ordering them to identify the names of hundreds of users who the RIAA believed were engaging in illegal file-sharing. For example, the Chronicle of Higher Education reported that the Illinois Institute of Technology, Loyola Marymount University, the University of California at Berkeley, the University of California at Los Angeles, and the University of Southern California were subpoenaed in 2003 for the names of alleged infringers [4].

Several important cases have helped to shape policy on university responsibility under the DMCA. RIAA v. Verizon, 2003, is one such case. The major issue in this case was whether the DMCA required Verizon to reveal the names of its ISP account holders who were accused of copyright infringement by the RIAA. Basing their decision on the ambiguity of the law and not addressing the broader constitutional questions, the court ruled against RIAA, stating that the DMCA allows a safe haven for an ISP that is merely a conduit for the information and does not store the information on computers owned by the ISP, except as temporary caches in the transit process [11]. Relying on the Verizon case, the Eighth Circuit Court of Appeals recently ruled in a similar manner, by granting the ISP's Motion to Quash the subpoena issued by the copyright holders [7].

Because of the challenges in obtaining information through pre-litigation subpoenas served on ISPs, copyright holders have begun seeking to discover the identities of copyright infringers through the filing of "John Doe" complaints. Elektra Entertainment v. John Doe represents such an action. In this case, the copyright holder sued several unnamed defendants, and then sought to obtain their identities by serving the ISP with subpoenas. The judge held that ISPs must notify these John Doe defendants of the subpoena and allow them twenty-one days to challenge the release of their information to the copyright holders [2]. The RIAA is undeterred in its efforts, and reports having filed more than 700 lawsuits against alleged copyright infringers on January $24,2005[10]$.

In the above cases, the Courts elected to rule based on a narrow DMCA statutory interpretation, rather than considering the underlying Constitutional issues presented by the DMCA. One would expect that these Constitutional issues will be addressed inevitably. Regardless, these cases do enable universities to resist pressure from copyright holders in their efforts to prosecute alleged copyright infringement.

The United States Supreme Court has accepted the opportunity to provide much needed guidance in the interpretation of DMCA. In March of 2005, the Court will hear oral arguments in the case of MGM v. Grokster [9]. The immediate issue in this case is whether the peer to peer file-sharing service developed by Grokster is legal. Like traditional video recorders, Grokster offers legitimate purposes even though its technology can also be used for illegal copying. Though the 
Court may attempt to limit its holding specifically to the facts of the Grokster case, its decision will have broader implications. A ruling for Grokster would enable universities to argue by analogy that they are exempt from much of the DMCA since the primary purpose of providing Internet access is for legitimate educational purposes, and illegitimate uses are inconsequential. A victory for MGM would raise the expectation that universities must monitor abuses more carefully.

\section{Examples of University Policies}

Universities had three possible responses to the DMCA: 1) ignore it; 2) adopt a new policy prohibiting illegal file sharing; or, 3) bring existing computer use policies into compliance with the DMCA. Obviously, the first idea was ill-fated. The second and third efforts are the focus of this article. Most universities now have policies in place which prohibit illegal file sharing. We focus on the possibility that some universities may have gone too far in their efforts to comply with the DMCA, at the expense of their students' due process rights.

Universities utilize various policies and approaches in an attempt to comply with the DMCA. These policies may be loosely defined as student friendly, neutral, and copyright friendly.

Student friendly policies often explain the risks of liability for copyright infringement, and notify students that their actions may subject them to discipline. For example, one university offers this advice to its students: "To avoid the risk of potential lawsuits due to copyright infringement, the college is advising students to carefully restrict the use of file sharing applications to material that is legal to share, to disable the file sharing software, or to change the file sharing options for the software....if you violate copyright law by engaging in unauthorized file sharing, you may be subject to discipline under the College's Computer Use Policy and other applicable College policies." [6].

Neutral policies attempt to balance the important issues property rights with the students' need for due process. Neutral policies clearly prohibit using university systems to violate copyright; however, they also afford students notice of the alleged infringement, and an opportunity to be heard. Neutral policies recognize the vital nature of Internet connectivity to college students, and reserve the right to terminate Internet access only upon repeat offenses. An example of a neutral policy will be provided later in this article.

Copyright friendly policies appear to exclusively focus on avoiding liability under the DMCA at all costs. For example, one university simply states: "If the University is informed that a network user has violated federal copyright law, the University will suspend that user's network privileges." [8]. Does a mere allegation of a copyright violation merit a suspension of network privileges? Another policy demonstrates a university's focus on liability avoidance: "The University may temporarily suspend, block or restrict access to an electronic mail account or University computing resources, independent of the University disciplinary procedures, in order to protect the integrity, security or functionality of University or other computing resources or to protect the University from liability." [12]. Presumably, state Universities have disciplinary procedures that afford students due process rights. Why should an investigation of alleged 
copyright violations operate independent of customary disciplinary procedures that assure due process protection?

While these few examples are far from a comprehensive sample of university policies, they do demonstrate that universities interpret their DMCA obligations in a diversity of ways. Some universities threaten to terminate Internet access based on a single accusation, while others use disciplinary procedures and require evidence of repeat offences before terminating access. All of the universities comply with the requirements that access to suspicious files be denied, but some universities provide a procedure allowing access to files to be reinstituted while others do not. While such differences may be justified based on differences of university mission, governance, risk tolerance, or others reasons, this paper argues that some of the policies may violate constitutional requirements of due process.

\section{Explanation of the Due Process Requirements for State Universities}

The Fourteenth Amendment to the federal Constitution states that no state shall deprive any person of life, liberty, or property without due process of law. The relevant issue then, is whether Internet access is a liberty interest. Though few courts have squarely addressed the issue, sufficient guidance exists for one to conclude that due process must be afforded students whose Internet privileges are denied at state colleges and universities.

A student's interest in pursuing an education is protected by the Fourteenth Amendment. The United States Supreme Court addressed this issue thirty years ago in the landmark case of Goss v. Lopez. In this case, the Court held that a student facing a suspension from a state educational institution was entitled to due process protections. While due process is a flexible standard, and what is due will vary depending on the interests at stake, the Court noted that in the context of a suspension, the student must at a minimum be given notice of the charges against him, and an opportunity to present his side of the story. The Court did acknowledge that prior notice need not be given when students pose a continuing danger to persons or property, or when students pose an ongoing threat of disrupting the academic process. In such cases, notice and a hearing must be provided "as soon as practicable." [5].

In the previous three decades, Goss v. Lopez has been cited with approval multiple times in other court cases, as well as in secondary sources. As of the date of this writing, the authors had found no published case involving a student's due process claim against a university for revoking Internet access in response to a DMCA notification. However, it is all but a foregone conclusion that eventually, this case will work its way through the judicial system.

One could argue that the revocation of Internet privileges is not as severe as a suspension. However, in today's educational climate, the loss of Internet access may be far more detrimental than a ten day suspension (the length considered in the Goss case). As professors increasingly utilize the Internet for instructional purposes, its use in many courses is essential. Policies that permanently suspend a student's Internet privileges based on a mere allegation made by a copyright holder are almost certain to violate due process if notice and an opportunity to be heard are not afforded. 
Important due process questions also exist when temporary restrictions are placed on a student's Internet use. The DMCA requires that universities must expeditiously remove or block access to infringing material. One of the outcomes of the Elektra case was a requirement of a twenty one day notice period prior to the dissemination by the ISP of user information pursuant to a subpoena. During this period, the individual alleged to have violated copyright law is afforded an opportunity to protest the allegations contained within the subpoena [2]. The Elektra decision, coupled with the Goss case, suggests that a university might be required to provide notice and an opportunity to be heard prior to removing or blocking access to infringing material. Recall that Goss v. Lopez required advance notice and a hearing unless students posed a continuing danger, or an ongoing threat of disrupting the academic process [5]. It is improbable that a student's alleged copyright infringement would disrupt the academic process to the extent contemplated by Goss.

\section{A Proposed Model Policy}

Any policy on copyright infringement adopted by a university must meet two requirements. First, the policy must clarify that the university does not facilitate illegal file sharing. Second, and equally important, the policy must not violate Constitutional requirements which give students the right to a fair procedure, since lost access to the Internet may be as punitive to today's students as suspension was to a previous generation. At a minimum, such a policy needs at least two parts. The first part is notification. Students must be made aware of what constitutes a violation of the DMCA and what the consequences of violating these policies might be. The consequences must be sufficient to act as a deterrent under the DMCA, but must also be drafted in light of the essential nature of the Internet to today's college students. Further, students must be notified of the specific allegation of misconduct.

The second part is the opportunity to be heard, as mandated by the due process clause of the fourteenth amendment. While students may not be entitled to a formal adversarial hearing, they must be afforded the opportunity to respond to the specific allegations made against them. Though it might be acceptable to deny access to certain files or programs based on allegations of wrong-doing, it seems unreasonable to completely deny access to the Internet based on these allegations. Further, even if temporary denial of Internet or file access may be justified, the permanent denial of access to files, programs, or the Internet should require a disciplinary procedure that assures the student will have the opportunity to be heard, as well as a right to appeal any disciplinary decision that permanently denies a student Internet access.

While the following should not be construed as legal advice, below is an example of a policy that we believe meets these requirements:

Notice: This University complies with the requirements of the Digital Millennium Copyright Act which protects copyrighted electronic materials. Students should not use file sharing applications to share or access material that is protected by copyright laws.

Procedure: Students who violate copyright law by engaging in unauthorized file sharing are subject to discipline according to the Student Conduct Manual, Computer Use manual, and other applicable policies. Students who are alleged to have committed illegal file-sharing are entitled 
to a hearing. If at all possible, the hearing will take place prior to adverse disciplinary action being taken. Students who elect to not avail themselves to the opportunity of a hearing may have their access to the Internet limited or temporarily denied, as the university may remove or block access to infringing material. Students who repeatedly violate the file-sharing policy may have their Internet access permanently terminated.

\section{CONCLUSION}

Advances in computer technology create new opportunities for learning and new problems for owners of intellectual property. The Digital Millennium Copyright Act attempts to provide protection for intellectual property, but has created a problematic situation for universities who want both to respect property rights and to protect their students' due process rights. This paper summarizes an issue that has yet to be addressed in the literature, the right of procedural justice for those accused of copyright infringement using the University Internet service. The paper examines a number of university policies on file-sharing and finds some to be deficient. Finally, the paper provides a model policy that provides for procedural justice in dealing with alleged illegal file-sharing.

\section{REFERENCES}

1. Digital Millennium Copyright Act, Pub. L. No. 105-304, 112 Stat. 2860 (1998).

2. Elektra Entertainment v. John Doe, No. 04-1241 (U.S. Dist. Ct. for Eastern Dist. Penn. Oct. 13, 2004).

3. Fonovisa v. Cherry Auction, 76 F.3d 259 (9 $9^{\text {th }}$ Cir. 1996).

4. Foster, A. (2003). Recording Industry Says It Will Sue Hundreds, Including Students, Starting This Month. Chronicle of Higher Education Online, Retreived September 12, 2003, from http://chronicle.com/prm/weekly/v50/i03/03a03001.htm

5. Goss v. Lopez, 419 U.S. 565 (1975).

6. Goucher College, Policies: Peer-to-Peer File Sharing and Copyright Law. Retrieved February 28, 2005, from http://www.goucher.edu/it/index.cfm?page_id=142

7. In re Charter Communications, Inc., Subpoena Enforcement Matter, 393 F.3d 771 ( ${ }^{\text {th }}$ Cir. 2005).

8. Long Island University (2005). Statement on Network Use. Retrieved February 28, 2005, from http://www.liu.edu/networkuse.html

9. Metro-Goldwyn-Mayer Studios Inc. v. Grokster, Ltd., 125 S.Ct. 686 (2004).

10. Recording Industry Association of America (2005). New Round of Lawsuits Against 717 Illegal File Sharers Includes Continued Focus On University Network Users Who Illegally Download Music. Retrieved February 28, 2005 from http://www.riaa.com/news/newsletter/012405.asp

11. Recording Industry Ass'n of America, Inc. v. Verizon Internet Services, Inc., 351 F.3d 1229 (D.C. Cir. 2003).

12. Saginaw Valley State University. (2005). Internet, Electronic Communications and Computing Resources acceptable Use Policy, 4.6-1. Retrieved February 28, 2005 from http://www.svsu.edu/operationsmanual/4.6-1.html

13. Sony v. Universal City Studios, 464 U.S. 417 (1984). 